\title{
Learning Analytics Contribution in Education and Child Development: A Review on Learning Analytics
}

\author{
Rahmadi Agus ${ }^{1}$, Suzani Mohamad Samuri ${ }^{1,2}$ \\ ${ }^{1}$ Faculty of Art, Computing and Creative Industry, \\ Universiti Pendidikan Sultan Idris, Tanjong Malim, Perak, Malaysia \\ ${ }^{1,2}$ National Child Development Research Centre, \\ Universiti Pendidikan Sultan Idris, Tanjong Malim, Perak, Malaysia \\ p20162002516@siswa.upsi.edu.my ${ }^{1}$, suzani@fskik.upsi.edu.my² \\ DOI: https://doi.org/10.37134/ajatel.vol8.4.2018
}

Received: 20 April 2018; Accepted: 10 July 2018; Published: 21 December 2018

\begin{abstract}
Learning Analytics is a new field of research that appears as a link between educator data and students. The Learning Analytics is also able to provide information about decision making to understand and optimise the learning process. Early childhood education is believed to be very important because the learner is open and always tries new things and is considered very meaningful for future processes in the development of all aspects of their personality. In this study, we aimed at investigating the application of learning analytics and how the learning process on child development in early childhood education. The Article Search Process is carried out on two databases, ScienceDirect and IEEE. In this study, the most important keywords are Learning Analytics and early childhood. The results of the search are 45 articles: (31/45) ScienceDirect and (14/45) IEEE, from 2012 to 2017. They are thoroughly explored in the Learning Analytics process, data collection and pre-processing, analysis and action, and post- processing. The process of data collection is done by implementing Online Systems or Game-Based Learning: 58\% e-Learning systems, 27\% Learning Analytics systems, and 15\% Game-based learning. Many research was conducted on samples from Post graduate, High school and Elementary school. The results showed that early childhood education had the advantage of the use of the new technology and in enchancing the child's knowledge and skills. Such as creativity and logical intelligence in the introduction of shapes and numbers. In the further study, the concept of Learning Analytics in the form of assessment and feedback that is given to support the improvement of the objectivity in the learning process by collaborating with educational games which can be another beneficial to the early childhood education. Objective assessment and feedback may be the monitor and prediction which will also be analised for the efficiency and effectiveness in the learning proces through the use of the technology.
\end{abstract}

Keywords: Learning Analytics, Learning, Early Childhood.

\section{INTRODUCTION}

Learning Analytics emerges as a link between educator data and students. The broad conceptualisation of the terms Learning Analytics defines as the measurement, collection, analysis and reporting of data about learners and the context, for the purpose of understanding and optimizing learning (Siemens \& Long, 2011). Learning Analytics as a measure, data collection, analysis, and reporting of learners and aims to understand and optimize learning and the environment in which it occurs (Tlili, Essalmi, Ayed, Jemni, \& Kinshuk, 2017). Learning analytics is also an intelligent data, data produced by students, and analysis models to find information and social relationships, and can provide advice to learners. Learning analytics encompasses the latest technologies, methods, models, techniques, algorithms, and cutting-edge practices that provide all members of the institutional community with a window into what really happens during the student learning path. 
Learning analytics offers insights into education that can endow with information on strategic decision making on resource allocation for educational excellence. Research shows that Learning Management Systems (LMS) support learning community and improve student's involvement and success (Macfadyen \& Dawson, 2010). Learning Analytics can supply powerful analytical tools for teachers and researchers who can support them in improving the effectiveness of their course management and collectively improving the quality of their students' performance as well as inform, extract and visualize real-time data about student involvement and possible student success (Macfadyen \& Dawson, 2010). Learning Analytics in cloud-based services, with results can help teachers and students to learn in new ways (Ebner, Prettenthaler, \& Hamada, 2014). For example, Masako Furukawa et al. In the development of learning analysis platforms for OUJ online courses, for detailed analysis of learning notes (Furukawa \& Yamaji, 2017), apply an app to track student's online learning activities based on LMS logs and semantic similarity between sentences in messages sent on the basis of information, indicating that a learner knows his rank in a more effective learning group (Al-Ashmoery $\&$ Messoussi, 2015). Thus, to get a better understanding on the process of Learning Analytics in the evaluation of educator data, this study would investigates the implementation of Learning Analytics and how the learning process for child's development in early childhood education.

\section{LITERATURE REVIEW}

\section{Learning analytics}

Learning analytics is one of education field. Experts in online learning in higher education identify behavior patterns to improve the quality of students in learning. Learning Analytics, educational data mining, and Academic Analysis are related concepts. Data mining education focuses on the development and delivery of methods with the aim of promoting the discovery of data in educational settings. The data mining tests patterns in a large set of data related to the actions of learners.

Next is analysis of learning. It is related to the development of methods that utilize a collection of educational data to support the learning process (Chatti, Dyckhoff, Schroeder, \& Thus, 2012). There are five criteria and quality indicators owned by learning analytics, they are objectives, learning support, learning measures and output, data aspects, and organizational aspects (Scheffel, Drachsler, Stoyanov, \& Specht, 2014). The purpose of learning analaytics itself is to match the challenges of the educational world to the needs and abilities of individual learners through actions such as interventions with risky learners or providing feedback and learning content. Thus, Learning Analytics guide policy makers to improve the quality of the learning process (Siemens \& Baker, 2012).

In a technology-mediated learning, students' involvement in cognitive and emotional experiences can serve as data to determine the impact of innovative learning practices (Henrie, Halverson, \& Graham, 2015). The concept of learning analytics seeks to improve the learning process through the systematic measurement of data related to learning and to provide informative feedback to learners and teachers. Information visualization and analysis of student participation are presented in the form of tools to provide feedback and information for stakeholders (Van Leeuwen, Janssen, Erkens, \& Brekelmans, 2014). Learning Analytics and educational games were developed to implicitly model the learner's personality based on their tracks during the learning-play process (Ali \& Ahmed, 2017; Cariaga \& Feria, 2015; Serrano-Laguna, Torrente, Moreno-Ger, \& Manjón, 2012; Tlili et al., 2017). Students' behavior patterns in educational games were investigated by performing Digital Game-Based learning activities by exploring the behavior patterns of students with high and low achievement students in educational games that can affect student achievement (Sung, Wu, Hwang, \& Lin, 2017). Learning Analytics applied as a new way of measuring and reporting children's learning, with mathematical content through PBS KIDS and literacy games for children ages 2 to 8 by developing a learning analytics platform to analyze back-end data from children's interactions with transmeed PBS KIDS content, and provide special reports to parents to identify and support their children in a better learning. Also, it allows contribution on students' outcomes, and explores the psychomotor nature of the game (Roberts, Chung, \& Parks, 2016). 


\section{Early childhood education}

Early childhood education is believed to be very important because the early childhood students are curious about the environment and are open to learning and trying new activities, so early childhood education is considered essential for their future (Hinostroza, Labbé, \& Matamala, 2013). Basically, early childhood education aims to facilitating growth and overall development of all aspects on the child's personality. In his learning, Early childhood can take advantage of the use of the new technology and gain many advantages in the improvement of knowledge and skills (Drigas, Kokkalia, \& Lytras, 2015). Children aged $2-5$ years spend much time with technology in the form of tablets or smartphones (Marsh et al., 2015; Neumann, 2018). Because the technology on the tablet or smartphones using multimodal features such as hearing, sight, and touch is very easy to use by children aged $2-5$ years by swiping, dragging, tapping, opening, and issuing applications (Marsh et al., 2015; Roskos, Burstein, Shang, \& Gray, 2014). The tablets or smartphone provide learning and exploration using touch-based digital tools that make things interesting for children (Huber et al., 2016; Neumann, 2016, 2018). The learning experience provided by the lastest technology offers an opportunity for children to gain more knowledge, and fun from playing games on the tablets or smartphone, Thus, the learning experience show a sense of joy and pleasure (Hui, Hoe, Ismail, Foon, \& Michael, 2014).

\section{METHODS}

In this paper, the most important keywords are "learning analytics", and "early childhood". Early childhood students are children under 5 years of age; therefore, we exclude studies related to children. We also limit our scope for English-language literature. On the other hand, the consideration of physical development and related fields were also important. E-Learning, analytics, education data mining, data mining, computer intelligence, and artifical intelligence. As in Tabel 1: Literature search key terms.

Tabel 1: Literature search key terms

\begin{tabular}{ll}
\hline Term Early Childhood & Term Learning Analytics \\
\hline Early Childhood/ Childhood / Child / Young Children / & Learning Analytics \\
Children / Preschool / Early Years / Kindergarten & Learning \\
& Learn \\
& Analytics \\
& E-Learning \\
& Education data mining \\
& Data mining \\
& Prediction \\
& Computer Intelligence \\
& Artifical Intelligence \\
& \\
\hline
\end{tabular}

\section{Information sources}

Two main databases were used to manage target article searched, those are: (1). The ScienceDirect database, and (2). The IEEE Xplore digital library, is a large the big and many cross-disciplinary research database. We also limit the search for articles, including: (1). Year, article from 2012 to 2017 to keep the sources are the latest research; (2). Article Type, articles that will be used in this study are review articles and research articles.

\section{Study Selection}

The first step in the selection process is the collection of articles from two selected databases that cover all knowledge and discipline in education. After that, a searching process was suggested by Cooper (1988) to synthesizing the literature (Avella, Kebritchi, Nunn, \& Therese Kanai, 2016). This systematic procedure helps formulate problems, collect data, evaluate data feasibility, analyze relevant data, and 
present results. In this study, the problem were the Learning Analytics process with Game-Based learning and the early childhood learning process using technology in education.

\section{Search}

We use a mixture of keywords that contain related topics according to Tabel 1: Literature search key terms. During the search process using combined by the "OR" and "AND operator. Each article that meets criteria sets out as an initial target in the mapping of the Learning Analytics and early childhood. The exact query text is shown at he top of Figure 1: Flowchat of study selection. As a result of queries from two databases, all articles will search process by scanning and filtering. The scanning and filtering process were done by reading (1). Title and Abstract, (2) Full Text.

\section{Data Collection}

In order to simplify the process of collecting data. A complete list of all selected articles was arranged in the appropriate categories, and compiled from various sources into one Microsoft Excel file. Selected articles with full text readings were reading thoroughly. It would produce many highlights and comments. Furthermore, the classification of articles would run into an enhanced taxonomy. The data set was provided in additional material as a complete reference for the results.

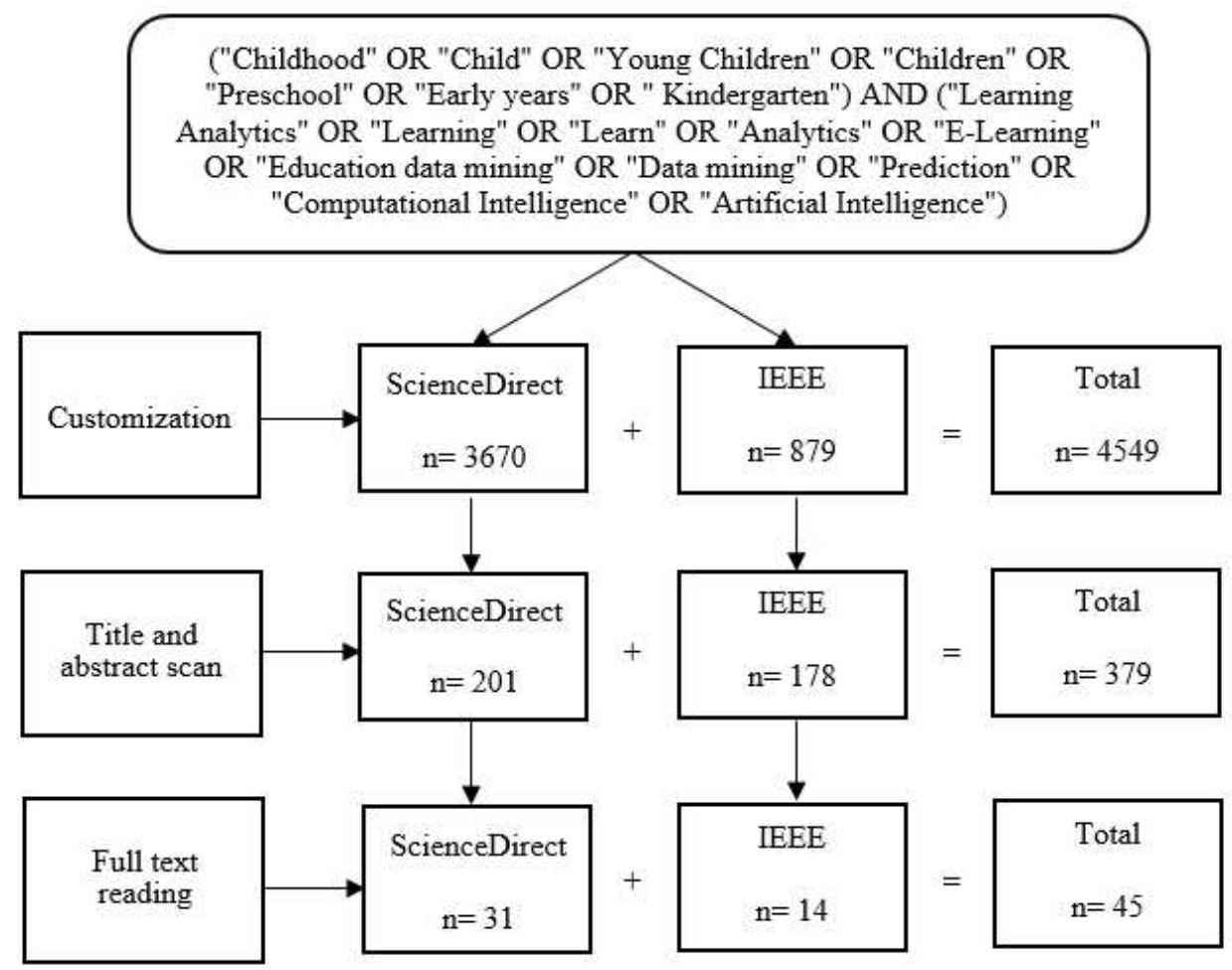

Figure 1: Flowchat of study selection

\section{RESULTS}

\section{Results of The Research}

In this section, we reviewed the results of searching and reviewing process. Firstly, we looked at trends in the contexts of Learning Analytics, and early childhood. Next, we set a description and an analysis of the high impact articles as determined by the number of citations and a review of the contributions made by these studies. The total numbers of the articles that collected were 45 articles. The table below 
is about the year of publication of 45 articles that published in two databases that related to categories of learning analytics and early childhood.

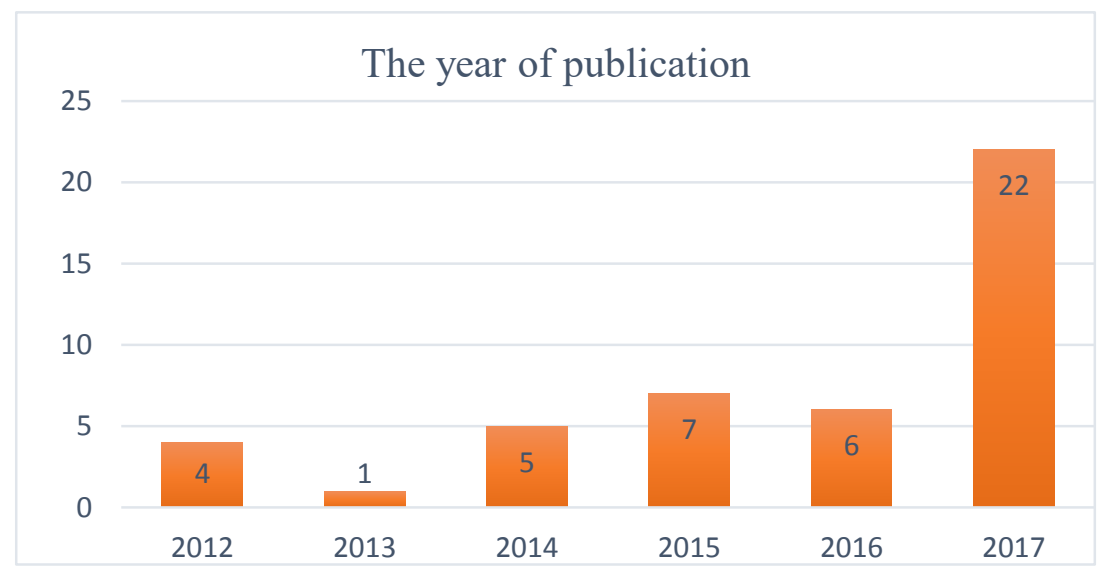

Figure 2 : The Articles Based on The Year of Publication

From the picture above, we had observed patterns in Learning Analytics, captured the general categories of research articles, and improved the classification into the taxonomy of the literature shown in Figure 3:Taxonomy of research literature on learning analytics.

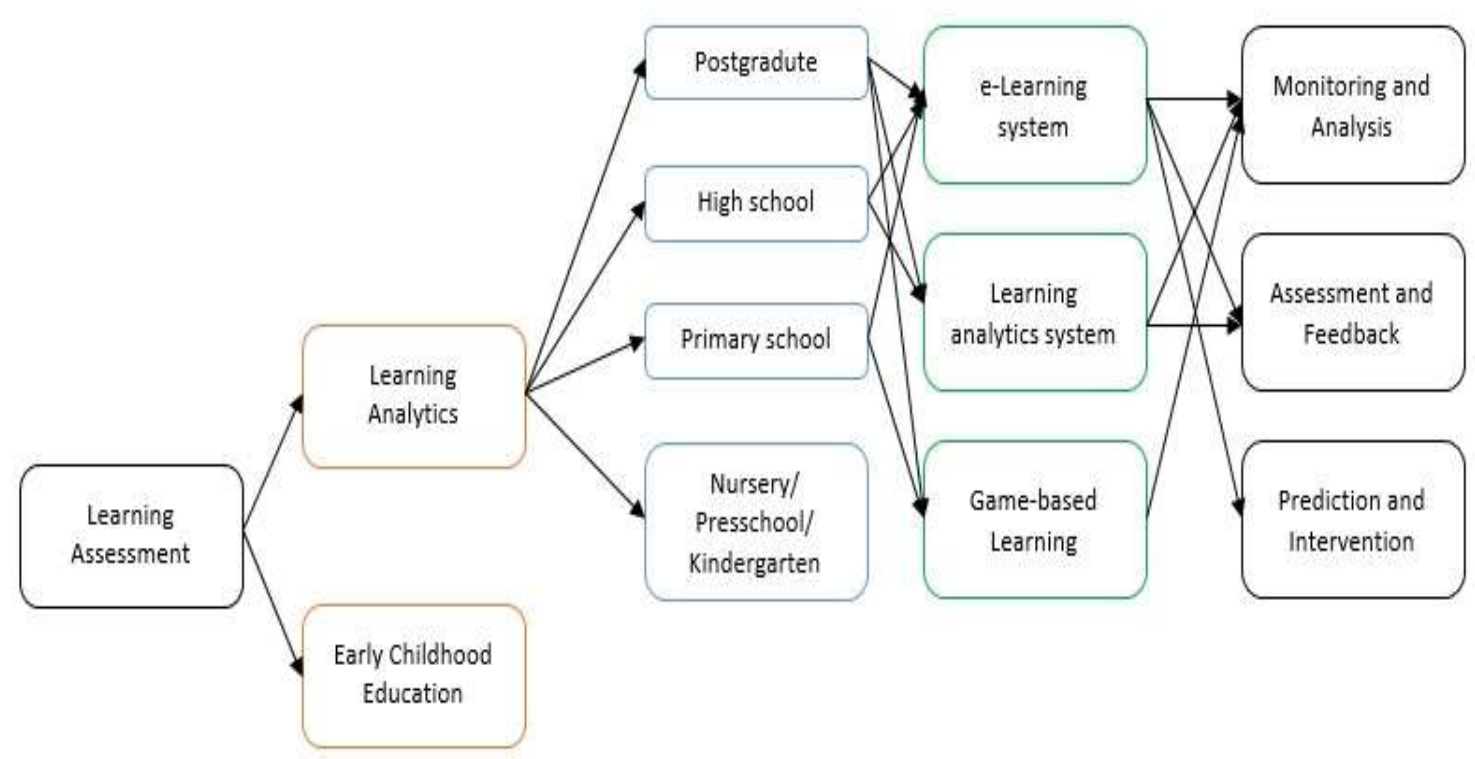

Figure 3:Taxonomy of research literature on learning analytics

From the picture above, the results of the analysis observe that most of the research was conducted on samples from the Post graduate, High School and Primary School. In general, learning analytics is related to the development of methods that utilizing educational data collections to support the learning process (Chatti et al., 2012). The concept of Learning Analytics are similar to the Educational Data Mining, and Academic Analysis (Castillo, 2016). It also similar to the process with data collection and pre-processing, analysis and action, and post-processing for the data collection system process that is used is the e-Learning system (Bodily \& Verbert, 2017). Learning analytics system and Game based learning. $58 \%$ of e-Learning systems, $27 \%$ of learning analytics systems, and $15 \%$ of game-based learning used for data collection, such as in Figure 4: Total system usage for data collection process. 


\section{Total system usage for data collection process}

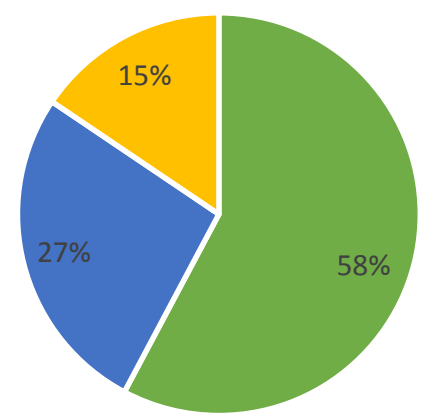

- e-Learning system

- Learning analytics system

- Game based learning

Figure 4: Total system usage for data collection process

Learning analytics contributes to groups of social students, by providing feedback and interactions that are visible and invisible. It also contributed on the possible influence of teachers' activities and differences between classes (Hernández-García, González-González, Jiménez-Zarco, \& ChaparroPeláez, 2015) as a measurement, learner data collection, analysis and reporting (Siemens \& Baker, 2012; Siemens \& Long, 2011). Based on four areas of Learning Analytics Dimensions, each area identifies various research challenges and opportunities as in objective learning analytics include monitoring, analysis, prediction, intervention, guidance or counseling, assessment, feedback, adaptation, personalization, recommendations, and reflection (Chatti et al., 2012). In Figure 3:Taxonomy of research literature on learning analytics, the number of publications is grouped based on the objectives of learning analytics, results as in Tabel 2: Objective identification in learning analytics.

Tabel 2: Objective identification in learning analytics.

\begin{tabular}{|l|l|}
\hline $\begin{array}{l}\text { Objective } \\
\text { Learning Analytics }\end{array}$ & \multicolumn{1}{|c|}{ Sources } \\
\hline Monitoring and Analysis & $\begin{array}{l}\text { (Daniel Spikol, 2017; Ebner et al., 2014; Fernández-Gallego, Lama, Vidal, \& } \\
\text { Mucientes, 2013; Furukawa \& Yamaji, 2017; Khalil \& Ebner, 2015; Manske et al., } \\
\text { 2014; Ruipérez-valiente, Muñoz-merino, Leony, \& Delgado, 2015; Shimada, Mouri, } \\
\text { \& Ogata, 2017; Srilekshmi, Sindhumol, Chatterjee, \& Bijlani, 2017; Sung et al., } \\
\text { 2017; Tlili et al., 2017; Vanessa Niet, Diaz, \& Montenegro, 2016; Yi et al., 2017) }\end{array}$ \\
\hline Assessment and Feedback & $\begin{array}{l}\text { (Ada \& Stansfield, 2017; Al-Ashmoery \& Messoussi, 2015; Ali \& Ahmed, 2017; } \\
\text { Muriuki, 2017; Shimada et al., 2017) }\end{array}$ \\
\hline Prediction and Intervention & $\begin{array}{l}\text { (Agudo-peregrina, Iglesias-pradas, Conde-gonzález, \& Hernández-garcía, 2014; } \\
\text { Aguilar \& Valdiviezo-Díaz, 2017; Dirk, Rienties, Mitterlmeier, \& Nguyen, 2018; } \\
\text { Laveti, Kuppili, Ch, Pal, \& Babu, 2017; Pappas, Giannakos, \& Sampson, 2017; } \\
\text { Serrano-Laguna et al., 2012) }\end{array}$ \\
\hline & \multicolumn{1}{|c}{} \\
\hline
\end{tabular}

Table 2 shows that learning analytics studies are grouped into objectives. Most of the objective research of learning analytics that is often done is (1) monitoring and analysis, (2) assessment and feedback, and (3) prediction and intervention. Monitoring and analysis is to track student activities and produce reports to support decision making, and refers to the evaluation of the learning process by the teacher with the aim of improving learning activities. Assessment and feedback is to support the assessment of 
improvement the efficiency and effectiveness of the learning process with feedback that provides information generated based on data about the learning context. For predictions and interventions, developing a predicts learning model based on activities and achievements and provides proactive intervention for students who need additional assistance (Chatti et al., 2012).

\section{Studies Conducted on Child Development}

We found that the study was conducted on children from our sample of 15 from 45 articles consisting of articles of children aged 2 - 4 years as many as 8 from 45 articles; aged $5-6$ years as many as 3 from 45 articles; aged 6 - 10 years as many as 4 from 45 articles. Literature on the profile of child development includes learning models, learning media, concepts of learning and early literacy education that needed by a child to improve his ability education (Papadakis \& Kalogiannakis, 2017).

\section{Discussion}

This study focused on literature review on learning analytics and early childhood, there are 45 articles from Science Direct and IEEE databases from 2012 to 2017. The results of the study revealed that learning analytics provides a comprehensive picture of the challenges in education. Although learning analytics is a new field of research, the approach in the education system is able to be a supporting source in the learning process. Early childhood education is very important to generate children towards changing in behavior, intellectual, moral, and social in order to become independent and social.

Learning analytics is a multi-disciplinary approach based on data processing, improving learning technology, education data mining, and data visualization. The purpose of learning analytics is to match the challenges of the education world with the needs and abilities of students through actions such as interventions by providing feedback and learning content, thus learning analytics is able to provide guidance in making policies to improve the learning process (Siemens \& Baker, 2012).

In the learning analytics process, data collection and pre-processing, analysis and action, and post-processing (Bodily \& Verbert, 2017). The process of data collection is done by implementing an online system or game-based learning. In the application of the online systems, much can be done in the process of implementing learning analytics. Previous research conducted data collection processes using e-Learning systems such as Massive Open Online Courses (MOOC) as one of the latest developments in the evolution of online learning, the application of learning analytics was used to identify students who were left behind in online courses to provide feedback that will help the students (Khalil \& Ebner, 2015). In addition, the MOOC has Moodle is a learning management system that can help and support teachers and researchers to understand and analyze patterns of interaction and construction of students' knowledge by implementing teaching and learning processes, student performance, and pedagogical practices that are applied for evaluation in Moodle smart class (AlAshmoery \& Messoussi, 2015). Real-Time System models can also be used in classrooms to gather activities during learning by collecting logs can be analyzing and presenting visual on an online-based system for teachers (Shimada et al., 2017).

Learning analytics and educational games are developed to implicitly a model the learners' personality based on their tracks generated during the learning-play process (Ali \& Ahmed, 2017; Cariaga \& Feria, 2015; Serrano-Laguna et al., 2012; Sung et al., 2017; Tlili et al., 2017). Student behavior patterns in educational games are investigated by using digital game-based learning activities. By exploring the behavior patterns of students with high and low achievement students in educational games that can affect on students' achievement (Sung et al., 2017). As in tabel 3 below, the previous research developed learning analytics with game-based learning to improve the learning process. 
Tabel 3: Research review learning analytics with game-based learning

\begin{tabular}{|c|c|c|c|}
\hline Author & Year & Title & Process \\
\hline $\begin{array}{l}\text { A. Tlili, F. Essalmi, L. Ayed et } \\
\text { al }\end{array}$ & 2017 & $\begin{array}{l}\text { A Smart Education Game to } \\
\text { Model Personality Using } \\
\text { Learning Analytics }\end{array}$ & $\begin{array}{l}\text { Modeling the learner's personality based on their tracks } \\
\text { generated during the learning-play process }\end{array}$ \\
\hline $\begin{array}{l}\text { M. Ali, S. Shatabda, and M. } \\
\text { Ahmed }\end{array}$ & 2017 & $\begin{array}{l}\text { Impact of Learning Analytics on } \\
\text { Product Marketing with Serious } \\
\text { Games in Bangladesh }\end{array}$ & $\begin{array}{l}\text { Serious Games (SG) with Learning Analytics in the } \\
\text { domain of product marketing }\end{array}$ \\
\hline $\begin{array}{l}\text { Serrano-Laguna, J. Torrente, } \\
\text { P. Moreno-Ger, and B.F } \\
\text { Manjon }\end{array}$ & 2012 & $\begin{array}{l}\text { Tracing a Little for big } \\
\text { improvements: Application of } \\
\text { Learning Analytics and } \\
\text { Videogames for Student } \\
\text { Assessment }\end{array}$ & $\begin{array}{l}\text { To measure the acquisition of knowledge covered by the } \\
\text { activity and also determine its effectiveness }\end{array}$ \\
\hline A.A Cariaga & 2015 & $\begin{array}{l}\text { Learning Analytics through a } \\
\text { Digital Game-Based Learning } \\
\text { Environment }\end{array}$ & $\begin{array}{l}\text { Develop a Learning Analytics model in a game-based } \\
\text { learning environment }\end{array}$ \\
\hline $\begin{array}{l}\text { H.Y. Sung, P.H. Wu, G.J. } \\
\text { Hwang, and D.C. Lin }\end{array}$ & 2017 & $\begin{array}{l}\text { A Learning Analytics Approach } \\
\text { to investigating the impacts of } \\
\text { Education Gaming Behavioral } \\
\text { Patterns on Students' Learning } \\
\text { Achievements }\end{array}$ & $\begin{array}{l}\text { Exploring behavioral patterns of educational games that } \\
\text { affect student achievement }\end{array}$ \\
\hline $\begin{array}{l}\text { Serrano-Laguna, J. Torrente, } \\
\text { P. Moreno-Ger, and B.F. } \\
\text { Manjon }\end{array}$ & 2014 & $\begin{array}{l}\text { Application of Learning } \\
\text { Analytics in educational video } \\
\text { games }\end{array}$ & Learn how students interact with the game \\
\hline $\begin{array}{l}\text { J.D. Roberts, G.K.W.K. } \\
\text { Chung, and C.B.Parks }\end{array}$ & 2016 & $\begin{array}{l}\text { Supporting children's progress } \\
\text { through the PBS KIDS Learning } \\
\text { Analytics Platform }\end{array}$ & $\begin{array}{l}\text { Provide special reports to identify and support children in } \\
\text { the process better }\end{array}$ \\
\hline
\end{tabular}

To early childhood education is believed to be very important because the early childhood students are curious about the environment and are open to learning and trying new activities, so early childhood education is considered meaningful for the future. Basically early childhood education aims to facilitate growth and overall development on the development of all aspects of the child's personality. In his learning that Early childhood can take advantage of the use of new technology and can gain many advantages in knowledge and skills (Drigas et al., 2015). The learning experience provided by technology now offers an opportunity for children to gain more knowledge, and fun from playing games on smartphones or tablets, from that they show a sense of joy or pleasure (Hui, Hoe, Ismail, Foon, \& Michael, 2014).

Toys had acquired digital characteristics and many children used them (Yilmaz, 2016) to shape the experience of early childhood students, improve their imagination and influence their behavior (Wang, Wu, \& Hsu, 2017). Learning basic concepts in early childhood education can be used in form of a game to improve children's early literacy education, reading skills, writing and math skills (Aladé, Lauricella, Beaudoin-Ryan, \& Wartella, 2016). Technology can make 2-5 years old children to get basic education, one of them is with tablets that use multimodal features such as hearing, vision, and touch. It means that the children can lear using the game provided in the playstore for free.

\section{CONCLUSIONS}

The review article shows that the general categories of learning analytics provide a comprehensive overview of the learning analytics method which is a liaison system between educators and students that aims to understand and optimize the learning process. Although learning analytics is a new field of research emerging in 2011 conducted by Siemens and Long, by approaching education data mining and learning analytics and knowledge that recommends collaborative research and various findings. Specifically data mining and learning analytics and knowledge can be shared with quality standards for research that enable it to be more effective and practical (Siemens \& Long, 2011). Many authors have 
defined and developed learning analytics in the last 2013 years, by enabling data collected in learning management systems (LMS) to problem in child development during the learning process. The learning analytics and game-based learning can encourage the creation of more effective educational games and also help produce the maximum in the learning process (Freire et al., 2016). Utilizing well-developed K-12 learning internationally, through the use of platforms such as computers, laptops, tablets, and mobile devices for child development processes in learning models that are able to foster children's literacy skills learning media and collaborative learning models in basic education can be used in early childhood education. On the other hand, using technology accelarate learning process, for example teaching the students using the technology which improves their creativity and logical intelligence in the introduction of shapes and numbers. Future research can also utilize the concept of learning analytics in the form of assessment and feedback in the collaborative of the educational games that is given to support the improvement of the efficiency and effectiveness of the learning process for early childhood education. In addition, to objective assessment and feedback, monitor and predictor of the learning process.

\section{ACKNOWLEDGEMENT}

This research study is supported by Ministry of Finance (MOF) through the Ministry of Education (MOE) Malaysia, under the National Child Data Center (NCDC) System Sustainability Project, 20180068-106-04. Special thanks to the National Child Development Research Centre (NCDRC), Universiti Pendidikan Sultan Idris (UPSI), for continuous support throughout the research.

\section{REFERENCES}

Ada, M. B., \& Stansfield, M. (2017). The Potential of Learning Analytics in Understanding Students' Engagement with Their Assessment Feedback. 2017 IEEE 17th International Conference on Advanced Learning Technologies (ICALT), 227-229. https://doi.org/10.1109/ICALT.2017.40

Agudo-peregrina, Á. F., Iglesias-pradas, S., Conde-gonzález, M. Á., \& Hernández-garcía, Á. (2014). Computers in Human Behavior Can we predict success from log data in VLEs? Classification of interactions for learning analytics and their relation with performance in VLE-supported F2F and online learning, 31, 542-550. https://doi.org/10.1016/j.chb.2013.05.031

Aguilar, J., \& Valdiviezo-Díaz, P. (2017). Learning analytic in a smart classroom to improve the eEducation. 2017 4th International Conference on eDemocracy and eGovernment, ICEDEG 2017, 32-39. https://doi.org/10.1109/ICEDEG.2017.7962510

Al-Ashmoery, Y., \& Messoussi, R. (2015). Learning analytics system for assessing students' performance quality and text mining in online communication. 2015 Intelligent Systems and Computer Vision (ISCV), 1-8. https://doi.org/10.1109/ISACV.2015.7105544

Aladé, F., Lauricella, A. R., Beaudoin-Ryan, L., \& Wartella, E. (2016). Measuring with Murray: Touchscreen technology and preschoolers' STEM learning. Computers in Human Behavior, 62, 433-441. https://doi.org/10.1016/j.chb.2016.03.080

Ali, M., \& Ahmed, M. (2017). Impact of Learning Analytics on Product Marketing with Serious Games in Bangladesh, 21-23.

Bodily, R., \& Verbert, K. (2017). Review of research on student-facing learning analytics dashboards and educational recommender systems. IEEE Transactions on Learning Technologies, 1-1. https://doi.org/10.1109/TLT.2017.2740172

Cariaga, A. A., \& Feria, R. (2015). Learning Analytics through a Digital Game-Based Learning Environment. IEEE. https://doi.org/10.1109/IISA.2015.7387992

Chatti, M., Dyckhoff, A., Schroeder, U., \& Thus, H. (2012). A reference model for learning analytics. International Journal, 9, 1-22. Retrieved from http://www.inderscienceonline.com/doi/abs/10.1504/IJTEL.2012.051815

Daniel Spikol. (2017). Estimation of Success in Collaborative Learning based on Multimodal Learning Analytics Features. https://doi.org/10.1109/ICALT.2017.122 
Dirk, T., Rienties, B., Mitterlmeier, J., \& Nguyen, Q. (2018). Student profiling in a dispositional learning analytics application using formative assessment. Computers in Human Behavior, 78, 408-420. https://doi.org/10.1016/j.chb.2017.08.010

Drigas, A., Kokkalia, G., \& Lytras, M. D. (2015). ICT and collaborative co-learning in preschool children who face memory difficulties. Computers in Human Behavior, 51, 645-651. https://doi.org/10.1016/j.chb.2015.01.019

Ebner, M., Prettenthaler, C., \& Hamada, M. (2014). Cloud-based service for eBooks using EPUB under the aspect of learning analytics. Proceedings - 2014 IEEE 8th International Symposium on Embedded Multicore/Manycore SoCs, MCSoC 2014, 116-122. https://doi.org/10.1109/MCSoC.2014.25

Fernández-Gallego, B., Lama, M., Vidal, J. C., \& Mucientes, M. (2013). Learning analytics framework for educational virtual worlds. Procedia Computer Science, 25, 443-447. https://doi.org/10.1016/j.procs.2013.11.056

Freire, M., Serrano-Laguna, Á., Manero, B., Martínez-Ortiz, I., Moreno-Ger, P., \& Fernández-Manjón, B. (2016). Learning Analytics for Serious Games. Learning, Design, and Technology. https://doi.org/10.1007/978-3-319-17727-4

Furukawa, M., \& Yamaji, K. (2017). Development of Learning Analytics Platform for OUJ Online Courses, (Gcce), 3-4.

Henrie, C. R., Halverson, L. R., \& Graham, C. R. (2015). Measuring student engagement in technologymediated learning: A review. Computers and Education, 90, 36-53. https://doi.org/10.1016/j.compedu.2015.09.005

Hernández-García, Á., González-González, I., Jiménez-Zarco, A. I., \& Chaparro-Peláez, J. (2015). Applying social learning analytics to message boards in online distance learning: A case study, 47, 68-80. https://doi.org/10.1016/j.chb.2014.10.038

Hinostroza, J. E., Labbé, C., \& Matamala, C. (2013). Computers \& Education The use of computers in preschools in Chile : Lessons for practitioners and policy designers. Computers \& Education, 68, 96-104. https://doi.org/10.1016/j.compedu.2013.04.025

Huber, B., Tarasuik, J., Antoniou, M. N., Garrett, C., Bowe, S. J., \& Kaufman, J. (2016). Young children's transfer of learning from a touchscreen device. Computers in Human Behavior, 56, 56-64. https://doi.org/10.1016/j.chb.2015.11.010

Hui, L. T., Hoe, L. S., Ismail, H., Foon, N. H., \& Michael, G. K. O. (2014). Evaluate children learning experience of multitouch flash memory game. 2014 th World Congress on Information and Communication Technologies, WICT 2014, 97-101. https://doi.org/10.1109/WICT.2014.7077309

Khalil, M., \& Ebner, M. (2015). A STEM MOOC for school children - What does learning analytics tell us? Proceedings of 2015 International Conference on Interactive Collaborative Learning, ICL 2015, (September), 1217-1221. https://doi.org/10.1109/ICL.2015.7318212

Laveti, R. N., Kuppili, S., Ch, J., Pal, S. N., \& Babu, N. S. C. (2017). Implementation of learning analytics framework for MOOCs using state-of-The-Art in-memory computing. Proceedings - 2017 5th National Conference on E-Learning and E-Learning Technologies, ELELTECH 2017, (1). https://doi.org/10.1109/ELELTECH.2017.8074997

Lonn, S., Aguilar, S. J., \& Teasley, S. D. (2015). Investigating student motivation in the context of a learning analytics intervention during a summer bridge program. Computers in Human Behavior, 47, 90-97. https://doi.org/10.1016/j.chb.2014.07.013

Macfadyen, L. P., \& Dawson, S. (2010). Mining LMS data to develop an "early warning system" for educators: A proof of concept. Computers and Education, 54(2), 588-599. https://doi.org/10.1016/j.compedu.2009.09.008

Manske, S., Hecking, T., Bollen, L., Gohnert, T., Ramos, A., \& Hoppe, H. U. (2014). A flexible framework for the authoring of reusable and portable learning analytics gadgets. Proceedings - IEEE 14th International Conference on Advanced Learning Technologies, ICALT 2014, 254-258. https://doi.org/10.1109/ICALT.2014.80

Marsh, J., Plowman, L., Yamada-Rice, D., Bishop, J., Davenport, A., Davis, S., ... Piras, M. (2015). Exploring play and creativity in pre-schoolers' use of apps : Report for the children's media industry Background to the project. University of Sheffield.

Muriuki, A. (2017). Learning Analytics : Supporting At-Risk Student through Eye-Tracking and a Robust Intelligent Tutoring System, 1002-1005.

Neumann, M. M. (2016). Young children's use of touch screen tablets for writing and reading at home: Relationships with emergent literacy. Computers and Education, 97, 61-68. https://doi.org/10.1016/j.compedu.2016.02.013

Neumann, M. M. (2018). Using tablets and apps to enhance emergent literacy skills in young children. Early Childhood Research Quarterly, 42(October 2016), 239-246. https://doi.org/10.1016/j.ecresq.2017.10.006 
Nikolova, A., \& Georgiev, V. (2017). A framework for evaluating and improving skills and knowledge of children up to 6 years of age. 2017 South Eastern European Design Automation, Computer Engineering, Computer Networks and Social Media Conference (SEEDA-CECNSM), 1-5. https://doi.org/10.23919/SEEDACECNSM.2017.8088229

Papadakis, S., \& Kalogiannakis, M. (2017). Mobile educational applications for children: What educators and parents need to know. International Journal of Mobile Learning and Organisation, 11(3), 256-277. https://doi.org/10.1504/IJMLO.2017.10003925

Pappas, I. O., Giannakos, M. N., \& Sampson, D. G. (2017). Fuzzy set analysis as a means to understand users of 21st-century learning systems: The case of mobile learning and reflections on learning analytics research. Computers in Human Behavior, 1-14. https://doi.org/10.1016/j.chb.2017.10.010

Roberts, J. D., Chung, G. K. W. K., \& Parks, C. B. (2016). Supporting children's progress through the PBS KIDS learning analytics platform. Journal of Children and Media, 10(2), 257-266. https://doi.org/10.1080/17482798.2016.1140489

Roskos, K., Burstein, K., Shang, Y., \& Gray, E. (2014). Young children's engagement with e-books at school: Does device matter? SAGE Open, 4(1). https://doi.org/10.1177/2158244013517244

Ruipérez-valiente, J. A., Muñoz-merino, P. J., Leony, D., \& Delgado, C. (2015). Computers in Human Behavior ALAS-KA : A learning analytics extension for better understanding the learning process in the Khan Academy platform, 47, 139-148. https://doi.org/10.1016/j.chb.2014.07.002

Scheffel, M., Drachsler, H., Stoyanov, S., \& Specht, M. (2014). Quality Indicators for Learning Analytics. Journal of Educational Technology \& Society, 17(4), 124-140. https://doi.org/10.1145/2567574.2567593 \r10.1145/2567574.2567591 \r10.1145/2567574.2567588

Serrano-Laguna, Á., Torrente, J., Moreno-Ger, P., \& Manjón, B. F. (2012). Tracing a little for big improvements: Application of learning analytics and videogames for student assessment. Procedia Computer Science, 15, 203-209. https://doi.org/10.1016/j.procs.2012.10.072

Shimada, A., Mouri, K., \& Ogata, H. (2017). Real-time Learning Analytics of e-Book Operation Logs for Onsite Lecture Support, 274-275. https://doi.org/10.1109/ICALT.2017.74

Siemens, G., \& Baker, R. S. J. (2012). Learning Analytics and Educational Data Mining : Towards Communication and Collaboration, 252-254.

Siemens, G., \& Long, P. (2011). Penetrating the Fog: Analytics in Learning and Education. EDUCAUSE Review, 46(2011), 30-32. https://doi.org/10.1145/2330601.2330605

Srilekshmi, M., Sindhumol, S., Chatterjee, S., \& Bijlani, K. (2017). Learning Analytics to Identify Students Atrisk in MOOCs. Proceedings - IEEE 8th International Conference on Technology for Education, T4E 2016, 194-199. https://doi.org/10.1109/T4E.2016.048

Sung, H.-Y., Wu, P.-H., Hwang, G.-J., \& Lin, D.-C. (2017). A Learning Analytics Approach to Investigating the Impacts of Educational Gaming Behavioral Patterns on Students' Learning Achievements. 2017 6th IIAI International Congress on Advanced Applied Informatics (IIAI-AAI), 564-568. https://doi.org/10.1109/IIAI-AAI.2017.224

Tempelaar, D. T., Rienties, B., \& Giesbers, B. (2015). In search for the most informative data for feedback generation: Learning analytics in a data-rich context. Computers in Human Behavior, 47, 157-167. https://doi.org/10.1016/j.chb.2014.05.038

Tlili, A., Essalmi, F., Ayed, L. J. Ben, Jemni, M., \& Kinshuk. (2017). A Smart Educational Game to Model Personality Using Learning Analytics. 2017 IEEE 17th International Conference on Advanced Learning Technologies (ICALT), 131-135. https://doi.org/10.1109/ICALT.2017.65

Van Leeuwen, A., Janssen, J., Erkens, G., \& Brekelmans, M. (2014). Supporting teachers in guiding collaborating students: Effects of learning analytics in CSCL. Computers and Education, 79, 28-39. https://doi.org/10.1016/j.compedu.2014.07.007

Vanessa Niet, Y., Diaz, V. G., \& Montenegro, C. E. (2016). Academic decision making model for higher education institutions using learning analytics. 2016 4th International Symposium on Computational and Business Intelligence (ISCBI), 27-32. https://doi.org/10.1109/ISCBI.2016.7743255

Vatavu, R. D., Cramariuc, G., \& Schipor, D. M. (2015). Touch interaction for children aged 3 to 6 years: Experimental findings and relationship to motor skills. International Journal of Human Computer Studies, 74, 54-76. https://doi.org/10.1016/j.ijhcs.2014.10.007

Wang, J. Y., Wu, H. K., \& Hsu, Y. S. (2017). Using mobile applications for learning: Effects of simulation design, visual-motor integration, and spatial ability on high school students' conceptual understanding. Computers in Human Behavior, 66, 103-113. https://doi.org/10.1016/j.chb.2016.09.032 
Yi, B., Wang, Y., Zhang, D., Liu, H., Shu, J., Zhang, Z., \& Lv, Y. (2017). Learning Analytics-Based Evaluation Mode for Blended Learning and Its Applications. 2017 International Symposium on Educational Technology (ISET), 147-149. https://doi.org/10.1109/ISET.2017.42

Yilmaz, R. M. (2016). Educational magic toys developed with augmented reality technology for early childhood education. Computers in Human Behavior, 54, 240-248. https://doi.org/10.1016/j.chb.2015.07.040 